\title{
Sedekah Kurikulum 2013: Sebuah Pendekatan Menanamkan Nilai-Nilai Luhur Pancasila Di Dunia Pendidikan Dengan Semangat Gotong Royong
}

\author{
Alphian Sahruddin \\ SD Negeri Kompleks IKIP I Makassar \\ phianshof86@gmail.com
}

\section{Article History}

accepted 01/12/2020

\begin{abstract}
Indonesia is known as a pluralistic nation. The number of ethnicities, tribes, religions, cultures and customs is the color of Indonesia's diversity. This difference makes Indonesian society a multicultural country. In building Unity and Unity which is the main capital of the strength of the Indonesian nation. One way that can be taken is by building solid cooperation among educators in developing and advancing education. Mutual cooperation is a form of active participation of each individual to be involved in giving added or positive value to every object, problem or need of the people around him. The concept of alms curriculum 2013 as an alternative practical solution to fostering teacher understanding in implementing the 2013 Curriculum. This alms curriculum 2013 has been implemented since July-September 2018 as many as 8 batches of alms curriculum 2013 have been able to train 678 teachers in the city of Makassar. All teachers who participated in this training generally followed the training with great enthusiasm. Activities are conditioned with an atmosphere of sharing and learning together. The characteristic nuance of alms makes participants more motivated. Participants understand more about the 2013 Curriculum mechanism where all participants have not been touched by the 2013 Curriculum training.
\end{abstract}

Keywords: Alms, Curriculum 2013, Mutual Cooperation

\begin{abstract}
Abstrak
Indonesia dikenal sebagai bangsa yang majemuk. Banyaknya etnis, suku, agama, budaya dan kebiasaan menjadi warna ke-Bhinekaan Indonesia. Perbedaan ini menjadikan masyarakat Indonesia sebagai negara Multikultural. Dalam membangun Persatuan dan Kesatuan yang menjadi modal utama kekuatan bangsa Indonesia. Salah satu cara yang dapat ditempuh dengan membangun kerjasama yang solid di antara Pendidik dalam mengembangkan dan memajukan pendidikan. Gotong Royong merupakan bentuk partisipasi aktif setiap individu untuk ikut terlibat dalam memberi nilai tambah atau positif kepada setiap objek, permasalahan atau kebutuhan orang disekitarnya. Konsep Sedekah K.13 sebagai alternatif solusi praktis untuk menumbuhkan pemahaman guru dalam melaksanakan implementasi Kurikulum 2013. Sedekah K.13 ini telah dilaksanakan sejak bulan Juli-September 2018 sebanyak 8 Batch Sedekah K.13 ini telah mampu melatih 678 orang guru di kota Makassar. Seluruh guru yang mengikuti pelatihan ini secara umum mengikuti pelatihan dengan penuh semangat. Kegiatan dikondisikan dengan suasana berbagi dan belajar bersama. Nuansa sedekah yang menjadi ciri khas menjadikan peserta lebih termotivasi. Peserta memahami lebih banyak lagi mekanisme Kurikulum 2013 dimana seluruh peserta memang belum tersentuh oleh pelatihan Kurikulum 2013.
\end{abstract}

Kata kunci: Sedekah, Kurikulum 2013, Gotong Royong

Social, Humanities, and Education Studies (SHEs): Conference Series https://jurnal.uns.ac.id/shes

p-ISSN 2620-9284 e-ISSN 2620-9292 


\section{PENDAHULUAN}

Pancasila dianggap sebagai sesuatu yang sakral. Setiap warga negara wajib menghafalkannya dan mematuhi segala isi yang terkandung dalam tiap sila-Nya. Sebagian besar warga negara Indonesia menganggap Pancasila sebagai sebuah dasar negara/ideologi semata tanpa memperhatikan makna yang terkandung dari tiap sila dalam kehidupan sehari-hari. Jika di cermati dengan seksama makna dan kandungan Pancasila sangat mendalam dan sangat bermanfaat dalam mebangun peradaban bangsa Indonesia.

Dalam dunia pendidikan dan kehidupan bangsa Indonesia peran Pancasila sangat dibutuhkan dalam mempererat persatuan dan kesatuan bangsa. Betapa tidak kondisi bangsa Indonesia yang begitu majemuk sangat rentan pertikaian. Kehadiran sebuah nilai yang universal yang dapat menyatukan segala perbedaan itu menjadi hal yang sangat perlu. Selain itu peran Pancasila sangat dibutuhkan yaitu sebagai dasar yang mempunyai arti bahwa Pancasila dijadikan sebagai pedoman dan sekaligus landasan dalam penyelenggaraan negara. Fungsi ini telah diimplementasikan dalam Pembukaan UUD 1945 yang kemudian menjadi sumber berbagai kebijakan publik di Indonesia.

Indonesia dikenal sebagai bangsa yang majemuk. Banyaknya etnis, suku, agama, budaya dan kebiasaan menjadi warna ke-Bhinekaan Indonesia. Perbedaan ini menjadikan masyarakat Indonesia sebagai negara Multikultural. Bila dikelola dengan baik multikulturalitas ini akan melahirkan sebuah energi yang hebat. Sebaliknya jika tidak dikelola dengan baik maka akan mengakibatkan sebuah bencana yang besar. Banyaknya penyimpangan yang terjadi berawal dari kesalahan memahami atau bahkan tidak mengamalkan dengan baik nilai-nilai yang terkandung dalam Pancasila. oleh karena itu penting memahami dan mengamalkan nilai yang terkandung bukan sekadar menghafalkan setiap sila-Nya. Pancasila terdiri dari dua kata yaitu Panca dan Sila. Nama Panca diusulkan oleh Ir. Soekarno sedangkan Sila diusulkan oleh salah seorang ahli bahasa. Pancasila dianggap telah sempurna dan mencakup segala aspek pada Bangsa Indonesia. (Asmaroini, 2017).

Kelangsungan hidup bangsa dan Negara Indonesia di era globalisasi mengharuskan kita untuk melestarikan nilai-nilai yang terkandung dalam Pancasila. Tujuannya agar generasi penerus bangsa tetap dapat menghayati dan mengamalkan seluruh nilai yang terkandung di dalamnya. Inti dari niai-nilai luhur itu tetap terjaga dan menjadi pedoman berbangsa dan bertanah air Indonesia sepanjang masa.

Pancasila telah mencakup tiga masalah hidup yang merupakan nilai-nilai hidup kemanusiaan yang terdiri dari prinsip-prinsip bagaimana seharusnya hubungan manusia dengan Tuhan, hubungan manusia dengan diri sendiri, dan hubungan manusia dengan segala sesuatu yang ada dalam dirinya (termasuk terhadap sesama manusia, sesama makhluk hidup, terhadap benda mati, alam maupun buatan manusia). Oleh karena itu, Pancasila dapat juga dinyatakan sebagai sebuah Falsafah hidup dan cita-cita luhur (ideologi) bangsa Indonesia yang mengatur tentang hubungan manusia dengan Tuhan, hubungan manusia dengan sesama Manusia, hubungan manusia dengan sesama bangsa, hubungan manusia dengan tanah airnya, dan hubungan manusia dengan harta benda (Soeprapto, 1995).

Isi dan arti Pancasila yang universal ini dijadikan sebagai prinsip dasar yang berlaku umum menjadi sumber dan landasan bagi pemecahan masalah dalam 
berbagai aspek kehidupan bangsa Indonesia. Masalah bangsa itu beraneka ragam baik dalam masalah kenegaraan, kebangsaan, maupun dalam kehidupan pribadi maupun kehidupan bermasyarakat. Sebab itu Pancasila sebagai Falsafah dan Bangsa Indonesia tidak dapat terpisahkan. Hubungan keduanya diatur dalam sebuah hubungan sebab akibat. Inti dari terminologi kata Tuhan, Manusia, Satu, Rakyat dan Adil merupakan bagian yang tidak terpisahkan dalam tatanan kehidupan berbangsa dan bernegara. Disatu pihak landasan Pancasila sebagai sebabnya dan bangsa Indonesia sebagai akibatnya (Soeprapto, 1995).

Sila ke-3 "Persatuan Indonesia" Pancasila yang bermakna filosofis sangat luar biasa yang diikrarkan oleh para pendiri bangsa Indonesia (founding father) untuk mempersatukan kemajukan yang dimiliki Indonesia sebagai sebuah kekayaan. Sebagai suatu totalitas, masyarakat memliki suatu kesatuan yang tidak hanya dalam arti lahiriyah, melainkan juga dalam arti batiniah, atau kesatuan ide yang menjadi fondamen kebangsaan (Besar, 1995 dalam Beridiansyah, 2017).

Ada sebuah ungkapan yang mengatakan bahwa kekayaan terbesar dari sebuah bangsa adalah manusianya, bukan sumber daya alamnya. Pernyataan tersebut tidaklah salah jika kita renungkan lebih bijaksana. Negara-negara maju seperti Jepang, Singapura, Korea Selatan bukanlah negara dengan jumlah kekayaan yang melimpah. Mereka menjadikan sektor utama membangun negaranya diawali dengan pembangunan Sumber Daya Manusianya. Untuk mewujudkan cita-cita itu tentu pendidikan merupakan jalan terbaik untuk menghasilkan manusia-manusia yang mampu membawa bangsanya menjadi negara maju bahkan super power.

Kenyataan yang terjadi di negeri kita, pendidikan masih berada pada tahap menentukan jati dirinya. Berulang kali kurikulum berubah namun belum menampakkan wajah Indonesia seperti diamanahkan dalam cita-cita perjuangan para pendiri bangsa yang tertuang dalam Pembukaan UUD 1945. Krisis multi dimensi masih terus melanda negeri ini ditambah lagi benih-benih pertikaian dan disintegrasi terus menggerogoti persatuan dan kesatuan yang telah lama disulam.

Dalam membangun Persatuan dan Kesatuan yang menjadi modal utama kekuatan bangsa Indonesia. Salah satu cara yang dapat ditempuh dengan membangun kerjasama yang solid di antara Pendidik dalam mengembangkan dan memajukan pendidikan. Multikulturalistik bisa menjadi penghalang tapi bisa menjadi kekuatan jika dibina dan dipelihara dengan baik. Perbedaan suku dan agama misalnya jika terus dicari perbedaannya maka yang terjadi adalah munculnya sikap merasa diri paling baik/benar dan cenderung menyalahkan yang tak segolongan dengannya. Perbedaan itu adalah fitrah yang tak bisa dihapuskan. Hal yang dapat kita lakukan adalah mencari dari sekian banyak perbedaan itu tentu ada nilai-nilai universal yang semua orang sepakat dan sepaham dengan itu. Salah satu cara meneguhkan rasa Persatuan dan Kesatuan adalah melalui kegiatan Gotong Royong. Gotong Royong merupakan bentuk partisipasi aktif setiap individu untuk ikut terlibat dalam memberi nilai tambah atau positif kepada setiap objek, permasalahan atau kebutuhan orang disekitarnya. Bentuk partisipasi itu dapat berupa bantuan yang berwujud materi, keuangan, tenaga fisik, mental spiritual, keterampilan, sumbangan pikiran yang membangun, sampai hanya berdoa kepada Tuhan yang Maha Esa.

Konsep berbagi atau bersedekah untuk kemajuan bersama jika dipelihara maka akan mendatangkan kebaikan bagi sesama. Bukan hanya yang satu golongan saja 
tetapi bisa memberikan manfaat bagi yang lainnya. Negara kita dibangun dengan semangat gotong royongnya. Begitu juga hal ini sangat jelas tertuang dalam Visi Kementerian Pendidikan dan Kebudayaan Indonesia "Mewujudkan Insan serta Ekosistem Pendidikan dan Kebudayaan yang Berkarakter dengan berlandaskan Gotong Royong".

Semua agama yang ada di Indonesia mempunyai pandangan yang sama tentang konsep sedekah. Sedekah dimaknai sebagai cara untuk berbagi kebaikan atau kelebihan harta terhadap sesama yang membutuhkan. Sedekah tidak dibatasi pada aspek materi atau harta saja tetapi sedekah bisa juga dalam bentuk nonmateril seperti tenaga, waktu, dan ilmu. Berbagi dan bersedekah terlebih lagi sangat bersesuaian dengan pengamalan sila ke-2 "Kemanuasian yang Adil dan Beradab" serta sila ke-5 "Keadilan Sosial Bagi Seluruh Rakyat Indonesia".

Sedekah adalah salah satu cara untuk mewujudkan sila ke-5 "Keadilan sosial bagi seluruh rakyat Indonesia". Hal ini terwujud melalui kepedulian terhadap sesama untuk memberi bantuan atau keringanan kepada pihak yang membutuhkan. Dalam perspektif Islam Sedekah bersal dari kata shadaqa yang berarti benar (Hafifuddin, 2002 dalam Ibrahim \& Handayani, 2009). Orang yang suka bersedekah adalah orang yang benar pengakuan imannya. Sedekah juga dapat bermakna jujur dan memberi dengan ikhlas (Bahmid, 2014). Orang-orang yang bersedekah berarti mereka berlaku jujur pada dirinya sendiri mengenai kelebihan yang Allah swt telah berikan padanya sehingga ia memberikan sedekah kepada yang membutuhkan dengan ikhlas mengharap kan keridhaan Allah swt.

Menurut istilah, sedekah berarti sesuatu yang dikeluarkan atau dilakukan oleh seseorang dari harta atau hal lainnya dengan tujuan mendekatkan diri kepada Allah swt (Bahmid, 2014). Dalam pengertian syariat sedekah sama dengan pengertian infak, termasuk juga di dalamnya hukum dan ketentuannya. Hanya saja kalau infak identik dengan materi maka sedekah memiliki arti yang lebih luas menyangkut hal yang bersifat nonmaterial. Jadi, makna sedekah sangat luas tidak terbatas pada sedekah harta. Sedekah yang paling ringan adalah senyuman, ucapan yang baik, salam kepada orang lain, sampai pada menafkahi keluarga lahir serta bathin (Sari \& Yulianawati, 2017).

Sedekah lebih utama diberikan kepada kaum kerabat atau sanak saudara terdekat sebelum diberikan kepada orang lain. Sedekah itu sebaiknya diberikan kepada orang yang betul-betul membutuhkan. Adapun bentuk atau barang yang yang disedekahkan tidak dibatasi namun harus merupakan yang sesuatu yang berkualitas baik dan disukai pemiliknya. Kurikulum 2013 pada dasarnya merupakan upaya penyederhanaan dan tematik integratif yang disiapkan pemerintah untuk mencetak generasi yang siap dalam menghadapi masa depan (Krissandi \& Rusmawan, 2017). Karena itu perlu menyusun sebuah kurikulum untuk mengantisipasi perkembangan masa depan. Kurikulum diaplikasikan dengan tujuan untuk mendorong peserta didik mampu lebih baik dalam melaksanakan keterampilan proses dalam proses pembelajaran. Permendikbud Nomor 65 Tahun 2013 menyatakan bahwa pembelajaran pada jenjang SD berdasarkan Kurikulum 2013 mengakomodasi pembelajaran tematikterpadu, keterpaduan lintas mata pelajaran, lintas aspek belajar, dan keragaman budaya. Setelah lahirnya Permendikbud Nomor 22 Tahun 2016 tentang Standar Proses maka Permendikbud Nomor 65 Tahun 2013 dinyatakan tidak berlaku. Sejalan 
dengan karakteristik dan cara belajar anak sekolah dasar usia 6-8 tahun, pembelajaran di sekolah dasar hendaknya mengusahakan suatu suasana yang aktif dan menyenangkan. Untuk itu berbagai prinsip pembelajaran aktif dan menyenangkan senantiasa harus diperhatikan oleh guru, antara lain: prinsip latar, prinsip belajar sambil bekerja, prinsip belajar sambil bermain dan prinsip keterpaduan (Indiarsih, 2005 dalam Krissandi \& Rusmawan, 2017).

Pembelajaran Kurikulum 2013 dirancang untuk mengembangkan aspek sikap, pengetahuan dan keterampilan yang dielaborasi oleh setiap satuan pendidikan (Permendikbud Nomor 20 Tahun 2016 tentang Standar Kompetensi Lulusan). Dalam Kurikulum 2013 juga dinyatakan bahwa penilaian pendidikan dilakukan sebagai proses pengumpulan dan pengolahan informasi untuk mengukur pencapaian hasil belajar peserta didik (Permendikbud Nomor 23 Tahun 2016).

Manusia pada dasarnya makhluk individu juga merupakan makhluk sosial (zoon politicon), oleh karena itu manusia memiliki karakteristik yang berbeda dengan lainnya (Rochmadi, 2012). Manusia selalu hidup secara berkelompok dengan sesamanya dan juga mempunyai kemampuan berkomunikasi dengan kelompok manusia lainnya. Kehidupan berkelompok ini didasari oleh kondisi keterbatasan kemampuan yang dimiliki oleh masing-masing individu dalam memenuhi kebutuhan hidupnya. Fakta lain mengungkapkan bahwa kebutuhan manusia selalu berubah dan berkembang. Potensi akal dan pikiran yang dimiliki manusia menjadikan selalu terjadi proses belajar dalam dirinya.

Didorong adanya perbedaan kemampuan manusia untuk memenuhi kebutuhan hidupnya meniscayakan manusia untuk hidup secara berkelompok. Keterbatasan dalam memenuhi kebutuhannya sendiri dan dibantu oleh akal pikiran yang dimilikinya, manusia secara alamiah membentuk sebuah kelompok-kelompok sosial. Berbagai manfaat serta keuntungan dari kerjasama dalam kelompok akan dirasakan oleh setiap individu. Kebiasaan hidup berkelompok dalam memenuhi kebutuhan hidup inilah yang menjadi cikal bakal kerjasama dan saling ketergantungan. Kerjasama ini dalam budaya Indonesia dikenal sebagai budaya Gotong Royong.

Gotong royong berasal dari kata dalam Bahasa Jawa. Kata Gotong dapat dipadankan dengan dengan kata pikul atau angkat. Kata Royong dapat dipadankan dengan bahasa Indonesia yaitu bersama-sama. Jadi secara sederhana kata Gotong Royong berarti mengangkat sesuatu secara bersama-sama atau juga diartikan sebagai mengerjakan sesuatu secara bersama-sama. Misalnya mengangkat meja yang dilakukan bersama-sama, membersihkan selokan yang dilakukan oleh warga juga termasuk bersama memecahkan masalah yang berat untuk dicari solusinya bersama. (Rochmadi, 2012).

Dari pengertian di atas dapat disimpulkan bahwa gotong royong merupakan bentuk partisipasi aktif setiap individu untuk ikut terlibat dalam memberi nilai tambah atau positif kepada setiap objek, permasalahan atau kebutuhan orang disekitarnya. Bentuk partisipasi itu dapat berupa bantuan yang berwujud materi, keuangan, tenaga fisik, mental spiritual, keterampilan, sumbangan pikiran yang membangun, sampai hanya berdoa kepada Tuhan yang Maha Esa. Untuk hal itulah penulis mencoba menggas sebuah gerakan untuk menumbuhkan semangat Gotong Royong di antara sesama pendidik dalam memajukan pendidikan di Indonesia melalui hal terkecil yang semua sepemahaman dengan itu. Gerakan dalam bentuk Sedekah Kurikulum 2013 
(Sedekah K.13) "sebuah pendekatan menanamkan nilai-nilai luhur pancasila di dunia pendidikan dengan semangat Gotong Royong". Cara ini kami tempuh untuk menghimpun kekuatan di tengah keterbatasan para guru maupun pendidik untuk mengimplementasikan kurikulum 2013 ditengah keterbatasan anggaran pemerintah untuk melakukan pembiayaan terhadap pelatihan guru.

\section{HASIL DAN PEMBAHASAN}

Tujuan dari penulisan best practice ini adalah untuk mengetahui implementasi gerakan Sedekah K.13 dalam menanamkan nilai-nilai luhur pancasila di dunia pendidikan dengan semangat Gotong Royong.

1. Implementasi Sedekah Kurikulum 2013 dalam menumbuhkan sikap Gotong Royong sebagai pengamalan nilai Pancasila

Perubahan dan perkembangan sektor pendidikan di Indonesia terus mengalami kemajuan dari tahun ke tahun. Perkembangan tersebut merupakan jawaban dari tuntutan untuk menyiapkan SDM (Sumber Daya Manusia) yang berdaya saing di era masyarakat global yang kian tak terbendung. Salah satu permasalahan yang dihadapi oleh pemerintah dalam sektor pendidikan yaitu masih rendahnya kualitas pendidikan disetiap jenjang, hal ini ditandai dengan rendah mutu lulusan lembaga pendidikan dan berbagai riset. Berbagai hasil survei mengungkapkan tingkat kompetensi SDM Indonesia masih dalam taraf yang memprihatinkan. Sebut saja hasil survei yang dirilis oleh PISA (Program for International Student Assessment) yang melakukan survey terhadap kemampuan penguasaan Sains dan Matematika. Pada tahun 2012 PISA merilis hasil survei tentang kemampuan siswa Indonesia dalam hal literasi dan kemampuan matematika berada pada posisi ke-64 dari 65 negara yang disurvei.

Pemerintah merupakan pihak yang bertanggung jawab akan rendahnya kompetensi SDM Indonesia. Tidak pernah berhenti melakukan perbaikan dalam rangka meningkatkan mutu pendidikan Indonesia salah satunya dengan terus melakukan penyempurnaan kurikulum. Sejak tahun 2013 hingga saat ini perbincangan hangat terkait Kurikulum 2013 terus mengalami tanggapan positif dan negatif (pro dan kontra).

Cara yang dilakukan oleh pemerintah dalam menjamin kesiapan sekolah dalam melakukan implementasi Kurikulum 2013 adalah melakukan pelatihan bagi guru dan tenaga kependidikan. Program pelatihan ini berlangsung sejak tahun 2016 hingga tahun 2017 terhadap kurang lebih 93.892 (60\%) sekolah sasaran. Pada tahun 2018, pendampingan sekolah sasaran untuk jenjang sekolah dasar ditambahkan lagi sebanyak $53.702(40 \%)$ sekolah tersentuh pelatihan dan diharapkan seluruhnya telah mampu melaksanakan Kurikulum 2013.

Praktek pelaksanaan pelatihan dan pendampingan implementasi Kurikulum 2013 tak lepas dari berbagai kendala. Ternyata program ini tidak menjangkau seluruh guru di Indonesia. Hanya guru perwakilan sekolah saja yang mengikuti pelatihan ini. Dalam satu sekolah hanya guru kelas I dan guru kelas IV saja yang mengikuti pelatihan. Sedangkan untuk guru kelas II, guru kelas III, guru kelas V dan guru kelas VI diharapkan belajar secara mandiri.

Hal yang terungkap dari hasil penelitian Federasi Serikat Guru Indonesia (FSGI) tahun 2013 mengenai pelatihan dan persiapan implementasi kurikulum 2013 di 17 kabupaten/kota di 10 provinsi di tanah air menunjukkan bahwa masih sangat banyak masalah penting sekaligus merupakan kegagalan dari pelaksanaan pelatihan persiapan guru. Pelatihan Kurikulum 2013 tidak menyentuh seluruh guru. Hanya perwakilan satu atau dua guru dalam satu sekolah yang mendapatkan pelatihan dan pendampingan. Akibatnya, pihak sekolah mengalami kesulitan karena 
guru sebagian besar tidak paham mekanisme implementasi Kurikulum 2013. (Ahmad, 2014)

Untuk mengatasi permasalahan yang diungkapkan diatas maka penulis mencoba merancang sebuah kegiatan pengembangan kompetensi guru dalam mengimplementasikan Kurikulum 2013 dengan konsep gotong royong. Kegiatan ini penulis beri nama Sedekah Kurikulum 2013 (Sedekah K.13). Tujuan dari program ini adalah untuk meningkatkan kemampuan dan motivasi guru dalam mengimplementasikan Kurikulum 2013 dengan semangat gotong royong yang dikemas dalam bentuk sedekah. Kegiatan ini dilaksanakan secara mandiri tanpa tergantung pada pelatihan yang dilaksanakan oleh pemerintah.

Akses untuk mengikuti pelatihan secara mandiri ini sangat terbatas. Proses implementasi Kurikulum 2013 yang terus mengalami revisi dalam rangka perbaikan. Guru yang telah mendapat pelatihan sebelumnya merasa tidak mampu untuk melakukan imbas ilmu karena mereka juga butuh penyegaran. Jika berlarut-larut maka yang terjadi di lapangan guru melaksanakan Kurikulum 2013 dengan pengetahuan secukupnya dan juga dalam keadaan terpaksa.

Hal ini tentu tidak produktif dan sangat berbahaya. Pengalaman penulis ketika melakukan komunikasi dengan beberapa rekan guru terungkap bahwa untuk di satu sekolah saja mereka kadang berbeda. Pengaturan jadwal dan pembelajaran yang seharusnya tematik tetapi masih mata pelajaran. Begitu juga dalam pengelolaan laporan hasil belajar siswa. Guru mengimplementasikan Kurikulum 2013 tetapi raportnya masih dalam bentuk Kurikulum 2006.

Konsep Sedekah K.13 penulis ambil sebagai alternatif solusi praktis untuk menumbuhkan pemahaman guru dalam melaksanakan implementasi Kurikulum 2013. Kata sedekah berasal dari bahasa Arab shadaqa yang berarti benar. Di dalam al-Qur'an kata shadaqa disebut sebanyak 85 kali. Sedekah secara umum adalah pemberian kepada orang lain tanpa melihat apakah yang diberi itu orang kaya ataupun orang fakir (Arifin, 2011 dalam Sari \& Yulianawati, 2017).

Dari Abu Hurairah r.a. berkata bahwa Rasulullah saw bersabda: Ucapan yang baik adalah sedekah". (H.R. Bukhori).

Jadi, makna sedekah sangat luas tidak terbatas pada sedekah harta. Sedekah yang paling ringan adalah senyuman, ucapan yang baik, salam kepada orang lain, sampai pada menafkahi keluarga lahir dan batin (Sari \& Yulianawati, 2017). Melalui konsep Sedekah K.13 ini guru dapat saling berbagi dan bersinergi. Tidak selamanya pelatihan pengembangan kompetensi guru harus bersumber dari pemerintah.

Mekanisme Sedekah K.13 ini sebenarnya sangat sederhana dan mudah untuk dilaksanakan dengan mengutamakan aspek Gotong Royong sebagai bentuk perwujudan nilai luhur Pancasila. Berikut akan kami uraikan teknis pelaksanaan Sedekah K.13:

a. Nama Kegiatan: Pelatihan Mandiri Sedekah K.13

b. Tujuan kegiatan: melatih sebanyak mungkin guru sehingga mereka memiliki motivasi dan pemahaman tentang mekanisme implementasi Kurikulum 2013.

c. Waktu pelaksanaan: waktu pelaksanaan pelatihan dilaksanakan selama 2 hari dengan durasi 32 JP dan pendampingan melalui Daring selama 1 bulan. Kegiatan dilaksanakan di akhir pekan seperti hari Sabtu dan Minggu atau di harihari libur. Biasa juga memanfaatkan waktu sepulang sekolah.

d. Peserta: guru yang belum pernah tersentuh pelatihan Kurikulum 2013 dibatasi 50-80 peserta untuk tiap angkatan.

e. Biaya: kegiatan ini gratis dan tidak memungut kontribusi dari peserta.

f. Tempat: aula atau ruangan yang mampu menampung seluruh peserta dan yang terpenting adalah nyaman dan gratis.

g. Narasumber: para Instruktur K.13 atau akademisi maupun pihak Dinas Pendidikan yang mau menyedekahkan ilmunya secara gratis. 
h. Konsumsi: mencari donatur yang mau bersedekah kepada guru, atau urunan sesama peserta untuk menanggulangi konsumsi.

i. Materi Diklat: Dinamika Perubahan Kurikulum 2013, Penguatan Pendidikan Karakter, Penerapan Literasi di Sekolah, Analisis SKL/KI/KD/Indikator, Pemetaan $\mathrm{KI} / \mathrm{KD}$, Penyusunan Prosem dan Prota, Menyusun Soal HOTS, Praktik penyusunan RPP dan Perangkat Pembelajaran, Penilaian Kurikulum 2013, Rencana Tindak Lanjut.

j. Sertifikat: di akhir pelatihan peserta mendapatkan sertifikat dengan pola dukung pelatihan durasi 32 JP dan pendampingan melalui Daring selama 1 bulan yang ditandatangani oleh ketua Tim Sedekah K.13.

2. Hasil dari pelaksanaan Sedekah Kurikulum 2013 dalam menumbuhkan sikap Gotong Royong dalam Dunia Pendidikan.

Sebelum melaksanakan kegiatan, tim sedekah K.13 terlebih dahulu meminta izin atau rekomendasi dari Dinas Pendidikan Kota Makassar. Setelah mendapatkan restu tim merilis pengumuman melalui media sosial. Seluruh peserta diwajibkan mendaftar secara online. Setiap 80 pendaftar dimasukkan ke dalam satu grup whatsapp. Seluruh peserta akan diberi pembekalan secara Daring sebelum melakukan pelatihan secara tatap muka.

Setelah seluruh peserta terkumpul maka mereka akan diberikan surat pemanggilan mengikuti pelatihan. Surat ini ditujukan kepada kepala sekolah masing-masing dengan harapan agar guru yang terpanggil dapat diberikan ijin atau penugasan mengikuti pelatihan. Salah satu syarat wajib peserta untuk mengikuti adalah harus terdaftar dalam surat pemanggilan dan juga harus mendapat ijin atau penugasan dari kepala sekolah.

Peserta telah siap maka selanjutnya tim Sedekah K.13 mencari donatur yang siap memfasilitasi tempat dan konsumsi selama pelatihan. Konsep kegiatan ini adalah gotong royong dalam bentuk sedekah berbagai pihak merasa terpanggil untuk terlibat mengambil bagian penting dalam kegiatan ini. Setiap tim Sedekah K.13 merilis pengumuman kegiatan untuk setiap Batch/Angkatan para donatur malah yang datang menawarkan diri. Mulai dari tempat pelatihan yang nyaman sampai konsumsi yang syarat gizi mereka berikan semata untuk membantu guru dan mengharapkan ridha Allah swt. Jika sekiranya pelatihan sudah akan dilaksanakan namun tim belum mendapatkan donatur untuk konsumsi maka peserta secara sukarela bergotong royong mengumpulkan sedekah terbaiknya untuk dimakan bersama oleh seluruh peserta pelatihan.

Kegiatan dengan nuansa berbagi inilah yang membuat setiap angkatan pelatihan ini berjalan lancar hampir tak ada masalah berarti. Bukan hanya dalam hal fasilitas maupun konsumsi, dari aspek narasumber kami selalu mendapatkan tawaran dari para relawan yang mau menyedekahkan ilmunya seputar Kurikulum 2013. Pada Instruktur Kota Makassar Kurikulum 2013, Dosen, bahkan unsur Dinas Pendidikan Kota Makassar berlomba mengambil bagian dari kerja ikhlas ini. Adapun capaian kegiatan pelatihan Sedekah K.13 yang telah kami lakukan selama tahun 2018 untuk setiap Angkatan dapat dilihat pada tabel 1.

Tabel. Capaian pelatihan Sedekah K.13 untuk tiap Angkatan

\begin{tabular}{|c|c|c|c|c|}
\hline Angkatan & Waktu Pelaksanaan & $\begin{array}{l}\text { Jumlah } \\
\text { Peserta }\end{array}$ & Unsur Peserta & Tempat \\
\hline 1. & $\begin{array}{l}\text { Sabtu-Minggu, } \\
21-22 \text { Juli } 2018\end{array}$ & 80 Orang & $\begin{array}{l}\text { Guru Kelas, Guru } \\
\text { PAI }\end{array}$ & $\begin{array}{l}\text { Aula Penerbit } \\
\text { Erlangga Makassar }\end{array}$ \\
\hline 2. & $\begin{array}{l}\text { Sabtu-Minggu, } \\
\text { 28-29 Juli } 2018\end{array}$ & 78 Orang & $\begin{array}{l}\text { Guru Kelas, Guru } \\
\text { PAI }\end{array}$ & $\begin{array}{lll}\text { Aula Serba } & \text { Guna } \\
\text { SIT Al } & \text { Izhar } \\
\text { Makassar } & \end{array}$ \\
\hline 3. & Sabtu-Minggu, & 80 Orang & Guru Kelas, Guru & Aula Serba Guna \\
\hline
\end{tabular}


SHEs: Conference Series 4 (2) (2021) 1 - 10

\begin{tabular}{|c|c|c|c|c|}
\hline & 4-5 Agustus 2018 & & PAl & \multirow{7}{*}{$\begin{array}{l}\text { Yayasan Mulia } \\
\text { Bhakti } \\
\text { Aula Penerbit } \\
\text { Erlangga Makassar } \\
\text { Aula Serbaguna } \\
\text { Persatuan Gereja } \\
\text { (PGl) Sulselbar } \\
\text { Aula Serba Guna } \\
\text { Madania School } \\
\text { Aula Serba Guna Ml } \\
\text { Al Hikmah } \\
\text { Makassar } \\
\text { Aula Penerbit } \\
\text { Erlangga Makassar } \\
\end{array}$} \\
\hline 4. & $\begin{array}{l}\text { Sabtu-Minggu, } \\
11-12 \text { Agustus } 2018\end{array}$ & 80 Orang & $\begin{array}{l}\text { Guru Kelas, Guru } \\
\text { PAI }\end{array}$ & \\
\hline 5. & $\begin{array}{l}\text { Sabtu-Minggu, } \\
\text { 18- } 19 \text { Agustus } 2018\end{array}$ & 120 Orang & $\begin{array}{l}\text { Guru Pend. } \\
\text { Agama Kristen }\end{array}$ & \\
\hline 6. & $\begin{array}{l}\text { Sabtu-Minggu, } \\
\text { 25- } 26 \text { Agustus } 2018\end{array}$ & 80 Orang & $\begin{array}{l}\text { Guru Kelas, Guru } \\
\text { PAI }\end{array}$ & \\
\hline 7. & $\begin{array}{l}\text { Sabtu-Minggu, } \\
\text { 1-2 September } 2018\end{array}$ & 80 Orang & $\begin{array}{l}\text { Guru kelas MI } \\
\text { KKM Kec. } \\
\text { Tamalate } \\
\text { Makassar }\end{array}$ & \\
\hline 8. & $\begin{array}{l}\text { Sabtu-Minggu, } \\
\text { 8-9 September } 2018\end{array}$ & 80 Orang & $\begin{array}{l}\text { Guru kelas MI } \\
\text { KKM Kec. } \\
\text { Bontoala } \\
\text { Makassar }\end{array}$ & \\
\hline & & 678 & & \\
\hline
\end{tabular}

Berdasarkan tabel 1 di atas dapat disimpulkan bahwa kegiatan Sedekah K.13 ini telah dilaksanakan sejak bulan Juli-September 2018 sebanyak 8 Batch. Total guru yang dilatih sebanyak 678 orang guru jenjang SD/MI dari berbagai latar belakang. Secara keseluruhan kegiatan berlangsung lancar tidak ada kendala yang berarti. Seluruh pihak mendukung sepenuhnya kegiatan Sedekah K.13 bahkan mereka berlomba untuk ikut ambil bagian di dalamnya.

Diakhir kegiatan pada setiap angkatan peserta diberikan kesempatan untuk menuliskan kesan, hal yang diperoleh dan rekomendasi setelah mengikuti pelatihan. Secara umum peserta sangat terkesan setelah mengikuti kegiatan diantaranya, 1) Pelatihannya menyenangkan; 2) Peserta sangat kompak untuk bersedekah; 3) pelatihannya luar biasa, keren dan inspiratif; 4) Pelatihan yang tidak hanya menambah ilmu tetapi menambah semangat beragama dan menambah teman baru; 5) Pemateri menyampaikan hal-hal yang sangat teknis dengan bahasa yang sederhana sehingga peserta mudah mengerti; 6) Pelatihan ini kami bisa saling berbagi masalah baik guru honorer dan guru PNS dapat berbaur dan mencari solusi bersama.

Hal yang diperoleh peserta diantaranya 1) Alhamdulilah kami sudah mengerti tentang K.13; 2) Momentum dimana saya bisa memahami apa itu K.13; 3) Banyak hal yang kami peroleh dari pelatihan ini; 4) Alhamdulilah kami tidak galau lagi dalam ber K.13; 5) Alhamdulilah masalah dalam penilaian K.13 tidak lagi sulit; 6) Keikhlasan berbagi semoga hal ini menular juga kepada guru yang lain; 7) Masalah dalam hal administrasi bisa terselesaikan; 8) Mengerti mengapa kurikulum harus berubah; 9) Kami bisa paham mengenai pembelajaran K.13 begitu juga penilaiannya; 10) Mengerti PPK, HOTS, GLS, dan Tematik.

Hal yang direkomendasikan peserta antara lain, 1) Sebaiknya ada panitia agar Narasumber tidak mengurusi hal-hal teknis; 2) Semoga lahir Instruktur-instruktur baru sehingga kegiatan seperti ini makin banyak; 3) Terus berjuang demi pendidikan Indonesia, jangan pernah lelah; 4) sebaiknya waktunya ditambah 1 hari lagi; 5) Pelatihannya tolong jangan hanya di wilayah Makassar saja; 6) Tolong bisa juga ke daerah karena masih banyak yang masih kesulitan seperti kami; 7) Semoga pemerintah mau menaruh kepedulian terhadap gerakan ini; 8) Pelatihannya jangan stop agar makin banyak guru yang terinspirasi. 


\section{SIMPULAN}

Sedekah K.13 ini merupakan sebuah kegiatan yang ditujukan meningkatkan kemampuan guru dalam memahami mekanisme implementasi Kurikulum 2013. Sedekah K.13 ini dikemas dalam bentuk kegiatan berbagi dalam bingkai Gotong Royong sebagai perwujudan nilai luhur Pancasila dari setiap Silanya. Selain itu kegiatan Sedekah K.13 ini diharapkan mampu menjadi motivasi guru dalam melaksanakan tugas sebagai guru. Keberhasilan implementasi Kurikulum 2013 ini sangat ditentukan oleh pemahaman dan motivasi guru. Dilaksanakan sejak bulan juliseptember 2018 Sedekah K.13 ini telah mampu melatih 678 orang guru di kota Makassar. Seluruh guru yang mengikuti pelatihan ini secara umum mengikuti pelatihan dengan penuh semangat. Kegiatan dikondisikan dengan suasana berbagi dan belajar bersama. Nuansa sedekah yang menjadi ciri khas menjadikan peserta lebih termotivasi. Peserta memahami lebih banyak lagi mekanisme Kurikulum 2013 dimana seluruh peserta memang belum tersentuh oleh pelatihan Kurikulum 2013.

\section{DAFTAR PUSTAKA}

Ahmad, S. (2014). Problematika kurikulum 2013 dan kepemimpinan instruksional kepala sekolah. Jurnal Pencerahan, 98-108.

Asmaroini, A. P. (2017). Menjaga eksistensi Pancasila dan penerapannya bagi masyarakat di era globalisasi . JPK: Jurnal Pancasila dan Kewarganegaraan, Vol. 2, 50-64.

Bahmid, S. B. (2014, Juli-Desember). Sedekah dalam pandangan Alquran. Retrieved from download.portalgaruda.org: http://download. portalgaruda.org/article.php?article=388471\&val=6442\&title=SED EKAH\%20DALAM\%20PANDANGAN\%20ALQURAN

Beridiansyah. (2017, Agustus 17). Membangun Persatuan dan Kesatuan Bangsa Dalam Kebhinekaan. Retrieved from http://jambi-independent.co.id: http://jambiindependent.co.id/read/2017/08/17/13605/membangun-persatuan-dan-kesatuanbangsa-dalam-kebhinekaan

Ibrahim, R., \& Handayani, T. (2009, Juli). Penerapan Pernyataan Standar Akuntansi Keuangan Nomor 45 Pada Baitul Mal Provinsi Nanggroe Aceh Darussalam. Retrieved from http://www.jurnal.unsyiah.ac.id: http://www.jurnal.unsyiah.ac.id/TRA/article/view/323/308

Krissandi, A. D., \& Rusmawan. (2017, Desember 4). Kendala Guru Sekolah Dasar dalam Implementasi Kurikulum 2013 . Retrieved from journal.uny.ac.id: https://journal.uny.ac.id/index.php/cp/article/view/7409/pdf

Kemdikbud. 2016. Permendikbud No. 20 Tahun 2016. Kemdikbud: Jakarta

Kemdikbud. 2016. Permendikbud No. 23 Tahun 2016. Kemdikbud: Jakarta

Rochmadi, N. (2012, November 20). Menjadikan Nilai Budaya Gotong-Royong Sebagai Common Identity dalam Kehidupan Bertetangga Negara-Negara ASEAN. Retrieved from http://library.um.ac.id: http://library.um.ac.id/images/stories/artikel_dosen/menjadikan\%20gotong\%20roy ong\%20sebagai\%20common\%20identity\%20-\%20nurhadi.pdf

Sari, A. C., \& Yulianawati, T. (2017). Sedekah Sebagai Media Pendidikan Karakter untuk Mengembangkan Kecerdasan Spiritual Anak Usia Dini. Retrieved from http://journal.stainkudus.ac.id:

http://journal.stainkudus.ac.id/index.php/thufula/article/view/2409/pdf

Soeprapto, S. (1995). Aktualisasi Nilai-nilai Filsafat Pancasila Notonagoro. Retrieved from http://i-lib.ugm.ac.id: http://i-lib.ugm.ac.id/jurnal/detail.php?datald=6538 